\title{
STUDY OF THE PROBABLE AMELIORATIVE EFFECT OF CROCIN ON MONOSODIUM GLUTAMATE-INDUCED CARDIOTOXICITY IN MALE ALBINO RATS
}

\author{
Dalia I.A. Mesallam¹, Omaima I. Abdel Hamid', Randa M. Kaf ${ }^{2}$ and Noha M. \\ Abedelsalam $^{3}$ \\ Forensic Medicine and Clinical Toxicology ${ }^{1}$, Pathology ${ }^{2}$ and Public Health and Preventive \\ Medicine $^{3}$ Departments, Faculty of Medicine, Zagazig University
}

\begin{abstract}
Monosodium glutamate (MSG) is a flavor enhancer used widely in modern nutrition. The current research aimed at studying the protective effect of Crocin, the main constituent of Crocus sativus L., on MSG-induced cardiotoxicity on male albino rats. The study was performed on 50 adult male albino rats randomly and equally divided into five groups: negative control, vehicle control (received $1 \mathrm{ml}$ saline/day), crocin group (treated with $20 \mathrm{mg} / \mathrm{Kg} /$ day crocin dissolved in $1 \mathrm{ml}$ saline), MSG group (received $3 \mathrm{~g} / \mathrm{Kg} /$ day MSG dissolved in $1 \mathrm{ml}$ saline) and MSG + crocin (treated with MSG and crocin in the same previously mentioned doses). All treatments were gavaged orally once daily for 8 weeks. The results showed that MSG exposure significantly increased total body weight and relative heart weight, serum interleukin (IL)-1 $\beta$, creatine kinase-myocardial band (CK-MB), Troponin I (CTnI). Also, MSG exposure significantly decreased serum level of IL-10. Cardiac oxidative stress parameters showed elevated malonedialdehyde (MDA) levels, decreased reduced glutathione (GSH) content and depressed cardiac antioxidant enzyme activities. 8hydroxy-2-deoxyguanosine $(8-\mathrm{OHdG})$ was increased significantly in comparison to the control groups. And there was significant increase in caspase-3 gene expression. These results were supported by histological and immune-histochemical alterations in the heart of MSG-treated rats. Notably, all these changes were partially ameliorated in rats treated concomitantly with MSG and crocin. The results of the present study showed that crocin exerts protective effects against MSG-induced cardiotoxicity in rats.
\end{abstract}

Keywords: Monosodium glutamate; Cardiotoxicity; crocin; Oxidative stress; 8OHdG; Caspase- 3

\section{INTRODUCTION}

Monosodium glutamate (MSG), a sodium salt of glutamic acid, is a substance broadly used as flavoring agent worldwide. It is added to food in quite small quantities either as a purified monosodium salt or as a constituent of a mixture of small peptides and amino acids to increase food palatability (Vindini et al., 2010).

This taste enhancer is added to a wide diversity of foods including snacks, flavored chips, prepared meals, packed and canned soups and sauces, manufactured meats, stuffed chicken, fresh sausages, some hams, flavored tuna and many types of canned and fast foods (Bojanic et al., 2009). In addition, glutamate naturally present in various kinds of foods including cheeses, seafood, meat broths, poultry and vegetables (Jinap \& Hajeb, 2010).

In 1959, Food and Drug Administration (FDA) classified MSG as a safe substance, but in 1995 the FDA reported that an unknown percentage of 
individuals may develop certain symptoms in response to MSG; these symptoms include nausea, headache, rapid heart rate, chest pain, bronchospasm, weakness, drowsiness and sweating. This reaction was termed as monosodium glutamate symptom complex (Krishna et al., 2010).

Despite being safe if taken in small amount in one type of food, the problem moves to a graver scale if consumed in higher amounts in different types of foods ingested daily. In addition, it is very difficult to determine what foods contain this taste enhancer since it falls under different labels (Hassan et al., 2014).

Several animal studies have shown that MSG is toxic to various organs as the liver, thymus, brain and kidneys (Diniz et al., 2004; Farombi \& Onyema, 2006; Pavlovic et al., 2009; Sharma et al., 2014). In addition, long-term ingestion of MSG was shown to result in hyperphagia, obesity, memory impairment, damage to hypothalamic neurons and asthma (Von Diemen et al., 2006; Williams \& Woessner, 2009).

Monosodium glutamate induced cardiotoxicity was previously recorded by Nayira et al. (2009); Paul et al. (2012). The MSG- induced organ toxicity may be related to oxidative stress and reduction of antioxidant defenses leading to damage of DNA and proteins. It may also be due to lipid peroxidation in cellular membranes with subsequent apoptosis (Diniz et al., 2004).

Crocin (crocetin di-gentiobiose ester) is the chemical component extracted from the saffron and the gardenia fruits (Gardenia jasminoides Ellis). It is universally acceptable as a phytotherapeutical drug because it is safe and has no side effects (Singla and Bhat, 2011).
Crocin is widely evaluated for its pharmacological actions such as anticancer (Abdullaev and Espinosa, 2004), anticonvulsant (Hosseinzadeh and Talebzadeh, 2005), and for treatment of memory impairment (Abe and Saito, 2000). Also, it is known as an effective anti-oxidant and modulates the oxidative damages in various tissues (Hosseinzadeh et al., 2009). Furthermore antioxidant activity of these compounds can guard DNA and RNA from harmful chemicals (Kanakis et al., 2009).

Several studies have aimed to counteract MSG toxicity, yet no previous trials have been made to studying the effects of crocin on MSG-induced cardiotoxicity. The aim of this work was to study the cardiotoxic effects of MSG in male albino rats and the possible protective effects of concurrent administration of crocin.

\section{MATERIAL \& METHODS \\ Material:}

(1) Chemicals:

- Monosodium glutamate (MSG): (C5 H9 NO4 .Na; purity >98\%) was purchased from Al-Dawlya Chemicals Company Cairo, Egypt.

- Crocin: (CAS number 42553-65-1; deep red powder with aromatic odor), was purchased from Sigma-Aldrich, Egypt.

\section{Animals and experimental design:}

Fifty adult male albino rats were weighing 180-200 g were obtained from animal house of Faculty of Medicine, Zagazig University. Before starting the experiment, the animals were subjected to 10 days period of passive prelimination to adapt themselves to the new environment, to ascertain their physical wellbeing and to exclude diseased animals. Rats were housed and maintained under 
standardized environmental conditions $\left(24 \pm 1{ }^{\circ} \mathrm{C}\right.$ away from any stress with a 12-hr light/dark cycle and $54 \pm 5 \%$ humidity). All rats had ad libitum access to standard rodent chow and filtered water. The present study was conducted in accordance with the international guidelines for animal research and after the approval of the Institutional Review Board on animal research at Faculty of Medicine - Zagazig University - Egypt

The rats were equally and randomly divided into five groups (10 rats/ each) and caged separately:

Group I (negative control group): this group received no treatment to measure the basic parameters.

Group II (vehicle control group): each rat received $1 \mathrm{ml} /$ day normal saline (solvent of crocin and MSG) orally by gavage

Group III (crocin treated group): each rat of this group received 20 $\mathrm{mg} / \mathrm{kg} /$ day freshly prepared crocin dissolved in $1 \mathrm{ml}$ saline orally by gavage. According to Goyal et al. (2010) this dose is effective in attaining the antioxidant defense and decreasing toxicity.

Group IV (MSG treated rats): each rat was treated with $3 \mathrm{~g} / \mathrm{kg} /$ day monosodium glutamate (Seo et al. 2010; Iamsaard et al. 2014), 1/5 oral LD50 (Kolawole 2013), dissolved in $1 \mathrm{ml}$ saline

Group V (MSG+crocin treated group): in this group each rat was treated with both monosodium glutamate and crocin concomitantly in the same previous doses.

All treatments extended for 8 weeks (sub-chronic exposure).

Twenty four hours after the last dose of treatment, the weight of every overnight fasting rat was recorded, and then animals were anesthetized through intra-peritoneal injection of $50 \mathrm{mg} / \mathrm{kg}$ pentobarbital. Blood samples were collected from retro-orbital plexus of each rat according to the method described by Parasuraman et al. (2010), the blood was left for spontaneous coagulation where serum was separated, centrifuged at 2500 $\mathrm{xg}$ for 15 minutes and kept at $-80{ }^{\circ} \mathrm{C}$ for subsequent biochemical investigations.

\section{Biochemical studies:}

The following biochemical parameters were estimated in Biochemistry Department, Faculty of Medicine, Zagazig University.

- Cardiac enzymes (serum CKMB and troponin I): Creatine kinase MB (CK-MB) level was measured in $\mathrm{ng} / \mathrm{ml}$ by enzyme-linked immunosorbent assay (ELISA) using rat CK-MB ELISA kit (cat. No KT-12247) from Kamiya Biomedical Company. Troponin I was measured also by ELISA using Life Diagnostics, rat cardiac Troponin I ELISA kit (cat. No CTNI-2-HS) following the manufacturer's instructions.

- Serum levels of interleukins (IL$1 \beta$ and IL-10): both were measured using commercially available rat ELISA kits from Thermo scientific, cat. No ER2IL1B for IL-1 $\beta$ and cat. No ERIL10 for IL-10, according to the manufacturers' instructions.

Then each rat was sacrificed, the heart was excised, washed in ice-cold phosphate buffered saline (PBS) and weighted and the relative heart weight was considered as the ratio of the absolute heart weight relative to total body weight multiplied by 100 . Two longitudinal sections from the ventricles of each heart were taken; the first was snap-frozen immediately in liquid nitrogen $(-170$ ${ }^{\circ} \mathrm{C}$ ) and stored at $-20{ }^{\circ} \mathrm{C}$ for further determination of oxidative stress parameters and caspase-3 gene expression. The second was fixed in 10 $\%$ neutral buffered formalin for $24 \mathrm{~h}$ 
and subjected directly to histological and immune-histochemical studies.

Oxidative stress parameters in cardiac tissue:

- Malondialdehyde (MDA): Bioxytech MDA-586 ELISA kit with Cat number 21044 was used in estimation of free MDA. The technique is based on the method explained by Erdelmeier et al. (1998); where part of heart tissue was thawed and homogenized in phosphate buffer solution with $\mathrm{pH} \quad 7.4$ then centrifuged for 10 minutes at $4000 x g$. The method is basically colorimetric where MDA reacts with the chromatogenic substance N-methyl-2-phenylindole (NMPI) to form carbocyanine where its color intensity can be measured spectophotometrically at $586 \mathrm{~nm}$

- Reduced glutathione (GSH): GSH recycling method described by Shaik and Mahvar (2006) was followed on the supernatant obtained after centrifuging homogenized part of the cardiac tissue in 5 volumes $5 \%$ cold sulfosalicylic acid at $14000 \mathrm{xg}$ and $4^{\circ} \mathrm{C}$ for 10 minutes. The colored compound 5 thio 2 nitrobenzoic acid, produced upon the reaction between GSH and 5,5'-dithiobis 2-nitrobenzoic acid (DTNB), can be measured spectrophotometrically at $405 \mathrm{~nm}$

- Catalase enzyme (CAT): the activity of catalase enzyme was assayed using Oxiselect ${ }^{\mathrm{TM}}$ catalase assay kit (Cat number STA-341) from Cell Biolabs, INC. The technique is based on the method explained by Aebi (1984); the enzyme catalyze a reaction between a known amount of $\mathrm{H} 2 \mathrm{O} 2,3,5$ dichloro 2- hydroxybezene sulfonic acid (DHBS) and 4- aminophenazone (AAP) to produce chromophore that can be measured at $520 \mathrm{~nm}$, its quantity is inversely comparative to the amount of catalase in the original sample.
Sample homogenization and assay was performed according to the kit instructions.

- Superoxide dismutase (SOD): the enzyme was quantified according to the technique designated by Nagi et al. (1995); the assess is centered on SODprovoked decrease in the level of nitroblue tetrazolium reduction to the blue formazan in alkaline media.

- 8-hydroxy-2-deoxyguanosine (8-OHdG): $8-\mathrm{OHdG}$ is considered a specific biomarker for the repair of oxidative DNA damage. 8-hydroxy-2'deoxyguanosine ELISA Kit with Cat number KA0444 (Abnova Co.) was used for its estimation. Two freezethaw runs of the cardiac homogenate were carried out to break down cell membranes then the homogenate was centrifuged for 5 minutes at $5000 \mathrm{xg}$ and the assay was completed on the supernatant following the kit instructions (Saito et al. 2000).

- Caspase-3 gene expression in cardiac tissue:

Quantitative real time PCR (qPCR) was used for estimation of caspase-3 gene expression in the ventricular tissue of all tested rats. RNeasy kit with Cat number 74104 (Qiagen, Germany) was used for extraction of the total RNA from cardiac tissue homogenate sticking to the kit instructions. The concentration of the total RNA was detected by quantifying the absorbance using ultraviolet spectrophotometer at $260 \mathrm{~nm}$. Reverse transcription was done and complementary DNA (cDNA) was synthesized using QuantiTect reverse transcription kit with Cat number 205310 (Qiagen, Germany) following manufacturer's instructions. Caspase-3 gene with forward 5'TGTTGTCCCTGTATGCCTCT-3' and reverse,

5 '- 
TAATGTCACGCACGATTTCC-3' was quantified and normalized in relation to the bases of $\beta$-Actin gene forward, $5^{\prime}-$ TGTTGTCCCTGTATGCCTCT-3' and reverse, TAATGTCACGCACGATTTCC-3' using qRT-PCR. SYBR Green RT-PCR amplification was performed using 25 $\mu \mathrm{L}$ reaction volume composed of $1 \mu \mathrm{L}$ each of the forward and reverse primer, $8.5 \mu \mathrm{L}$ distilled water, $2 \mu \mathrm{L}$ of cDNA and $12.5 \mu \mathrm{L}$ Roche Diagnostics SYBR Green RT-PCR Master Mix. Every sample was done in duplicate. The three steps of PCR included: 40 denaturation cycles at $95^{\circ} \mathrm{C}$ for 10 seconds, annealing at $55^{\circ} \mathrm{C}$ of 10 seconds and extension at $72^{\circ} \mathrm{C}$ for 20 seconds. The relative quantity of caspase-3 RT-PCR gene transcript was calculated in comparison to $\beta$-Actin gene using the formula described by Pfaffl (2001).

\section{Histological and immune- histochemical study:}

The heart sample of each rat was fixed immediately in 10\% formalin saline solution, embedded in paraffin and sectioned at thickness of $5 \mu \mathrm{m}$ then examined under light microscope after staining with haematoxylin and eosin according to the method described by

\section{Bancroft and Layton (2013).}

For immune-histochemical examination of caspase-3 a parafiiin section from each rat was subjected to dewaxing, dehydration, washing with phosphate buffer solution, and blocking using peroxide blocking stain. Antigen retrieval was performed by incubation at room temperature for 10 minutes in a humidity chamber. Then incubation with mouse monoclonal caspase-3 antibody Cat number MS-1123-R7 (Lab Vision Corporation, Fermont, CA 94538, USA) for one hour at room temperature in humidity chamber. Following removal of extra buffer, every section was incubated in prepared strept avidin peroxidase. Diaminobenzidine tetrachloride (DAB) was applied on each slide for 5-15 minutes until the appearance of brown color. According to Sternberger (1986), Mayer's haematoxylin was used for counterstaining. The cytoplasm of each caspase- 3 cell was stained brown. The brown staining was sorted as follows: no brown color $(-)$ (negative), faint brown staining (+) (mild positivity), moderate brown staining $(++)$ (moderate positivity) and strong brown staining (+++) (marked positivity).

\section{STATISTICAL ANALYSIS:}

The collected data were expressed as mean \pm standard deviation. The statistical analysis was done by Epi-info statistical package program version 6.04d, 2001. Correlation coefficient was done by Excel-Office 2007. Statistically significant differences were determined by one-way analysis of variance (ANOVA) followed by post hoc test for the multiple comparison among different groups. Probability value (p) less than 0.05 is considered significant.

\section{RESULTS \\ Body weight and relative heart weight: \\ Regarding body weight, there was no statistically significant difference between negative control, vehicle control and crocin treated group; while the body weight of MSG treated group showed statistically significant increase $(231.5 \pm 8.2)$ compared to negative control group (189.5 \pm 8.6$)$. Co- administration of crocin with MSG}


significantly decreases the body weight $(192.8 \pm 12.3)$ toward normal values (table 1).

On comparing negative control, vehicle control and crocin treated group there was no significant difference regarding the mean values of relative heart weight. Meanwhile, MSG administration induced a significant upsurge in relative heart weight $(0.8 \pm 0.08)$ in comparison with control group rat values $(0.5 \pm 0.03)$. The relative heart weight values in MSG+crocin group is significantly lower than those of MSG treated group $(0.6 \pm 0.06)$ (table 1)

Serum levels of interleukins (IL$1 \beta$ and IL-10):

The mean values of serum IL- $1 \beta$ and IL-10 revealed a non-significant difference between the negative control, vehicle control and crocin groups. Administration of MSG caused a significant increase in serum IL-1 $\beta$ level (176.5 \pm 3.8$)$ and a significant decrease in serum IL-10 (41.2 \pm 3.7$)$ when compared with the negative control group levels (116.9 \pm 2.28 \& $85.3 \pm 2.7$ respectively). Furthermore, concurrent administration of crocin with MSG ameliorated the MSGinduced IL-1 $\beta$ elevation and IL-10 reduction (148.4 $\pm 3.02 \&$ \& $68.7 \pm 3.97$ respectively) (table 2 ).

The IL-10: IL-1 $\beta$ ratio decreased from 0.73 in control rats to 0.23 in MSG treated rats. Co-administration of crocin with MSG caused restoration of the balance between pro-inflammatory and anti-inflammatory cytokines where the ratio increased to 0.46 .

\section{Cardiac enzymes biomarkers:}

Monosodium glutamate treated group showed a significant increase in the cardiac injury markers $\mathrm{CK}-\mathrm{MB}$ and $\begin{array}{llll}\text { troponin I } & (3.9 \pm 1.37 \quad \& \quad 2.9 \pm 0.5\end{array}$ respectively) when compared to negative control, vehicle control, and crocin treated group. Crocin coingestion significantly moderate the increase in cardiac enzymes levels $(1.18 \pm 0.6 \quad \& 1.2 \pm 0.18$ respectively) (table 2).

\section{Cardiac oxidant stress parameters:}

- Malondialdehyde (MDA): MSG administration significantly increased cardiac MDA tissue levels $(87.1 \pm 1.6)$ when compared to control values (67.0 \pm 1.5$)$. Adding crocin to MSG in group $\mathrm{V}$ resulted in a significant reduction in cardiac MDA level $(69.1 \pm 2.99)$ in comparison to rats of MSG group (Table 2).

- Reduced glutathione: table 2 showed that MSG administration resulted in a significant decline in cardiac GSH content $(8.09 \pm 1.4)$ in relation to control groups $(16.1 \pm 0.9)$. Crocin supplementation in group $\mathrm{V}$ caused restoration of $\mathrm{GSH}$ content in cardiac tissue to near control values

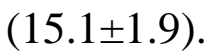

- Antioxidant enzymes (CAT, SOD): cardiac tissue contents of CAT and SOD were significantly lower in MSG treated group $(69.4 \pm 6.0$ \& $65.1 \pm 7.4$ respectively) in comparison to the control groups $(96.6 \pm 2.02 \&$ $71.6 \pm 5.3$ respectively). The values were significantly elevated in MSG+ crocin treated group $(88.6 \pm 6.83 \& 73.4 \pm 5.2$ respectively) when compared to MSG treated group (table 2).

- 8-Hydroxy-2-deoxyguanosine (8-OHdG): MSG triggered a significant rise in the cardiac tissues level of $8-\mathrm{OHdG}(62.4 \pm 9.0)$ compared to the control rats $(40.1 \pm 5.2)$. Crocin administration in combination with MSG significantly decreased the 8- 
OHdG level $(51.8 \pm 10.5)$ in comparison to the MSG treated group (table 2).

- qRT-PCR relative gene expression of caspase-3: Caspase-3 gene expression was increased significantly in the MSG group in comparison with the control groups. The caspase-3 expression displayed a significant drop upon concurrent treatment with crocin and MSG (Fig. 1).

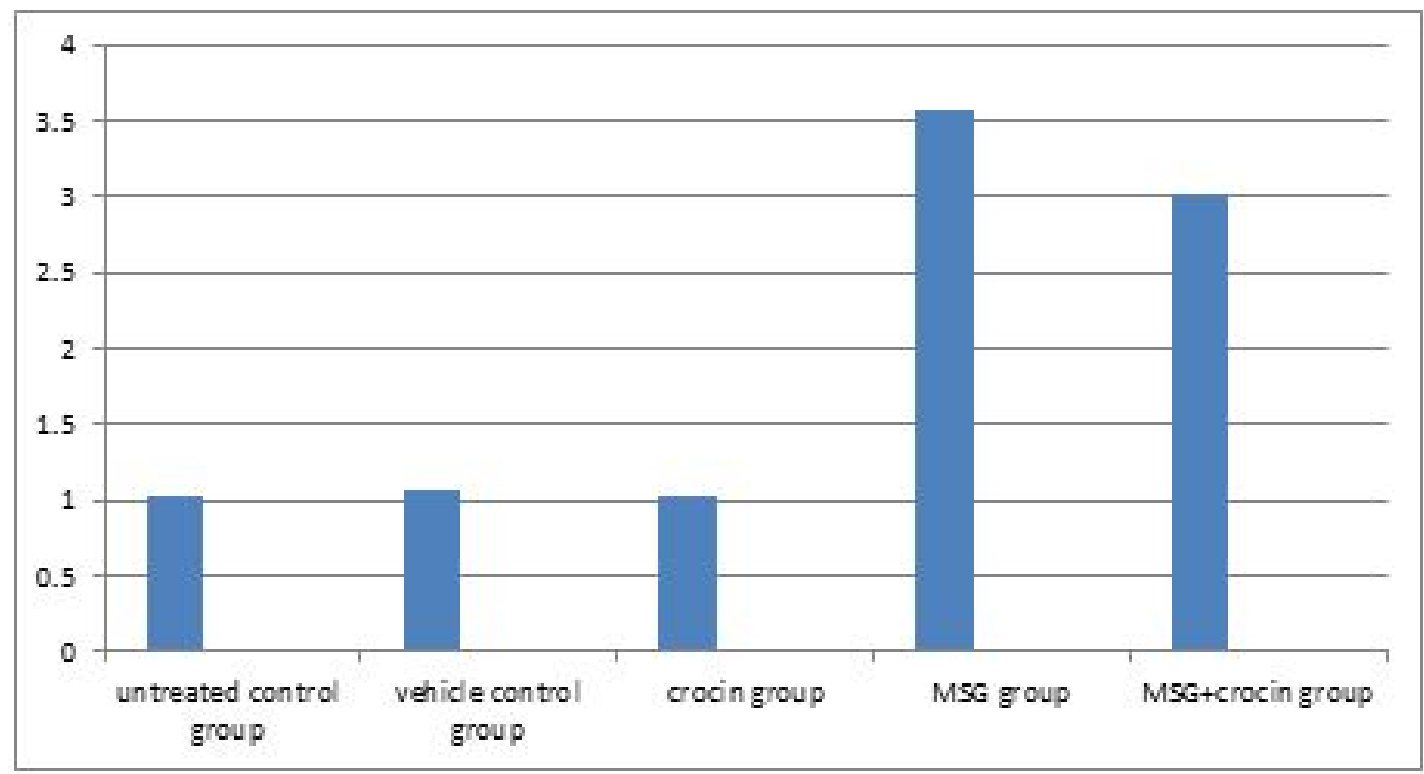

Figure (1): Bar chart showing comparison of mean values of caspase 3 gene expression by quantitative real time PCR among different studies groups.

The previous results revealed that the serum level of IL-1 $\beta$ was positively correlated to body weight $(\mathrm{r}=0.8$, $\mathrm{p}<0.001)$ and cardiac tissue MDA level $(\mathrm{r}=0.9, \mathrm{p}<0.001)$. On the other hand, it was negatively correlated to cardiac GSH level ( $\mathrm{r}=-0.86, \mathrm{p}<0.001)$, cardiac catalase level $(\mathrm{r}=-0.89, \mathrm{p}<0.001)$ and cardiac SOD level $(\mathrm{r}=-0.4, \mathrm{p}<0.001)$ (table 3).

In addition, serum IL-10 was positively correlated to the cardiac tissue levels of GSH $(\mathrm{r}=0.89, \mathrm{p}<0.001)$, CAT $\quad(r=0.9, \quad p<0.001)$ and SOD $(\mathrm{r}=0.42, \quad \mathrm{p}<0.001)$, while it was negatively correlated to cardiac MDA level $(\mathrm{r}=-0.93, \mathrm{p}<0.001)$ (table 3).

Furthermore, the significant increase in the activity of serum cardiac injury markers were positively correlated with lipid peroxidation (cardiac MDA; $r=0.85 ; \mathrm{P}<0.001$ with
CK-MB and $\mathrm{r}=0.94 ; \mathrm{P}<0.001$ with troponin I). Also, their levels were positively correlated with cardiac 8OHdG $(\mathrm{r}=0.60 ; \mathrm{P}<0.001$ with CK$\mathrm{MB}$ and $\mathrm{r}=0.75 ; \mathrm{P}<0.001$ with troponin I) and caspase-3 gene expression $(\mathrm{r}=0.7$; $\mathrm{P}<0.001$ with $\mathrm{CK}$ $\mathrm{MB}$ and $\mathrm{r}=0.8 ; \mathrm{P}<0.001$ with troponin I) (table 3).

\section{HISTOPATHOLOGICAL RESULTS:}

Examination of haematoxylin and eosin stained sections from negative control, vehicle control and crocin treated groups revealed normal architecture of the myocardium in the form of normal branching and anastomosing myocardial muscle fibers with oval centrally located nuclei and connective tissue composed of 
fibroblasts with flat dark nuclei (fig. 2 A, B).

However, examination of haematoxylin and eosin stained sections from MSG treated group revealed myocardial cell damage including degeneration of the cardiac muscle fibers and congested blood vessels in addition to pyknotic nuclei and inflammatory cellular infiltration (fig. 2 C, D). It was found that administration of crocin in combination with MSG in group $\mathrm{V}$ moderated those myocardial lesions as the myocardium showing near normal cardiac architecture with slight congestion and few inflammatory cells (fig. 2 E, F).

\section{IMMUNOHISTOCHEMICAL RESULTS:}

Negative control, vehicle control and crocin treated groups exhibited a negative caspase-3 immune reaction (fig 3 a, b), while MSG treated rats' sections showed widespread areas of strong positive $(+++)$ immune reaction (fig 3 c). MSG+crocin treated group showed weak to moderate positive caspase-3 immune reaction (fig 3 d). Using fisher exact test revealed that there was statistically significant difference in the degree of caspase-3 immune reaction among different studied groups (table 4)

Table (1): Statistical comparison of rats' body weight and relative heart weight at the end of treatment period among the studied groups:

\begin{tabular}{|c|c|c|c|c|c|c|c|}
\hline Group & $\begin{array}{l}\text { Negative } \\
\text { control } \\
\text { group } \\
\text { (I) }\end{array}$ & $\begin{array}{l}\text { Vehicle } \\
\text { control } \\
\text { group } \\
\text { (II) }\end{array}$ & $\begin{array}{l}\text { Crocin } \\
\text { treated } \\
\text { group } \\
\text { (III) }\end{array}$ & $\begin{array}{l}\text { MSG } \\
\text { treated } \\
\text { group } \\
\text { (IV) }\end{array}$ & $\begin{array}{l}\text { MSG+Crocin } \\
\text { treated } \\
\text { group } \\
(\mathrm{V})\end{array}$ & $\mathbf{F}$ & $\mathbf{P}$ \\
\hline \multicolumn{8}{|c|}{ Mean \pm SD } \\
\hline $\begin{array}{l}\text { Body weight } \\
\text { (g) }\end{array}$ & $189.5 \pm 8.6$ & $188.5 \pm 8.5$ & $188.5 \pm 7.1$ & $231.5 \pm 8.2 \mathrm{a}$ & $192.8 \pm 12.3 a, b$ & 42.2 & $0.000 *$ \\
\hline $\begin{array}{l}\text { Relative } \\
\text { heart } \\
\text { weights } \\
(\%)\end{array}$ & $0.5 \pm 0.03$ & $0.5 \pm 0.04$ & $0.5 \pm 0.03$ & $0.8 \pm 0.08 \mathrm{a}$ & $0.6 \pm 0.06 \mathrm{a}, \mathrm{b}$ & 51.3 & $0.000 *$ \\
\hline
\end{tabular}

Number of rats/group $=\mathbf{1 0}$

* significant

a Significant as compared to negative and vehicle control groups, $P<0.05$

b Significant as compared to MSG treated group, $P<0.05$ 
Table (2): Statistical comparison of serum interleukins (IL-1及, IL-10), cardiac enzymes biomarkers (CK-MB, troponin I) and cardiac oxidative stress biomarkers (MDA, GSH, CAT, SOD, 8-OHdG) among the studies groups:

\begin{tabular}{|c|c|c|c|c|c|c|c|c|}
\hline \multirow{2}{*}{\multicolumn{2}{|c|}{ Groups }} & $\begin{array}{l}\text { Negative } \\
\text { control } \\
\text { group } \\
\text { (I) }\end{array}$ & $\begin{array}{l}\text { Vehicle } \\
\text { control } \\
\text { group } \\
\text { (II) }\end{array}$ & $\begin{array}{c}\text { Crocin } \\
\text { treated } \\
\text { group } \\
\text { (III) }\end{array}$ & $\begin{array}{c}\text { MSG } \\
\text { treated } \\
\text { group } \\
\text { (IV) }\end{array}$ & & \multirow{3}{*}{$\begin{array}{c}\mathbf{F} \\
\\
\mathbf{9 3 8 . 5}\end{array}$} & \multirow{3}{*}{$\begin{array}{r}\mathbf{P} \\
\\
0.000 *\end{array}$} \\
\hline & & \multicolumn{5}{|c|}{ Mean \pm SD } & & \\
\hline & $\begin{array}{c}\text { IL-1及 } \\
(\mathrm{Pg} / \mathrm{ml})\end{array}$ & $\begin{array}{c}116.9 \pm \\
2.28\end{array}$ & $\begin{array}{c}117.2 \pm \\
2.6\end{array}$ & $\begin{array}{c}117.5 \pm \\
1.5\end{array}$ & $\begin{array}{c}176.5 \pm \\
3.8 \mathrm{a}\end{array}$ & $\begin{array}{c}148.4 \pm \\
3.02 \text { a,b }\end{array}$ & & \\
\hline & $\begin{array}{c}\text { IL-10 } \\
(\mathrm{Pg} / \mathrm{ml})\end{array}$ & $85.3 \pm 2.7$ & $\begin{array}{c}84.5 \pm 2 . \\
8\end{array}$ & $\begin{array}{c}84.5 \pm \\
2.22\end{array}$ & $\begin{array}{c}41.2 \pm 3 \\
7 \mathrm{a}\end{array}$ & $\begin{array}{c}68.7 \pm 3 . \\
97 \text { a,b }\end{array}$ & 363.9 & $0.000 *$ \\
\hline & $\begin{array}{l}\text { CKMB } \\
\text { (ng/ml) }\end{array}$ & $\begin{array}{l}0.344 \pm \\
0.026\end{array}$ & $\begin{array}{l}0.35 \pm \\
0.03\end{array}$ & $\begin{array}{l}0.352 \pm \\
0.033\end{array}$ & $\begin{array}{l}3.9 \pm \\
1.37 \text { a }\end{array}$ & $\begin{array}{l}1.18 \pm \\
0.6 \text { a,b }\end{array}$ & 137.706 & $0.000 *$ \\
\hline & $\begin{array}{c}\text { Troponin } \\
\text { I } \\
(\mathbf{n g} / \mathrm{ml})\end{array}$ & $\begin{array}{c}0.17 \pm \\
0.03\end{array}$ & $\begin{array}{c}0.22 \pm \\
0.07\end{array}$ & $\begin{array}{c}0.17 \pm \\
0.04\end{array}$ & $\begin{array}{l}2.9 \pm \\
0.5 \mathrm{a}\end{array}$ & $\begin{array}{c}1.2 \pm \\
0.18 \text { a,b }\end{array}$ & 254.9 & $0.000 *$ \\
\hline & $\begin{array}{c}\text { MDA } \\
\text { (nmol/g } \\
\text { tissue) }\end{array}$ & $67.0 \pm 1.5$ & $\begin{array}{c}67.0 \pm 1 . \\
4\end{array}$ & $\begin{array}{c}66.7 \pm 1 . \\
3\end{array}$ & $\begin{array}{c}87.1 \pm 1 \\
6 \text { a }\end{array}$ & $\begin{array}{c}69.1 \pm 2 . \\
99 \mathrm{~b}\end{array}$ & 224.904 & $0.000 *$ \\
\hline 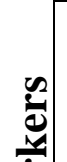 & $\begin{array}{c}\text { GSH } \\
\text { (mmol/g } \\
\text { tissue) }\end{array}$ & $16.1 \pm 0.9$ & $\begin{array}{c}16.2 \pm 0 . \\
7\end{array}$ & $\begin{array}{c}15.9 \pm 0 . \\
7\end{array}$ & $\begin{array}{c}8.09 \pm 1 \\
4 \mathrm{a}\end{array}$ & $\begin{array}{c}15.1 \pm 1 . \\
9 \mathrm{~b}\end{array}$ & 81.4 & $0.000 *$ \\
\hline 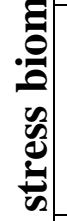 & $\begin{array}{l}\text { CAT } \\
\qquad(\mathrm{U} / \mathrm{g} \\
\text { protein) }\end{array}$ & $96.6 \pm 2.02$ & $\begin{array}{c}96.3 \pm 4 \\
3\end{array}$ & $\begin{array}{c}99.9 \pm 3 . \\
3\end{array}$ & $\begin{array}{c}69.4 \pm 6 \\
0 \text { a }\end{array}$ & $\begin{array}{c}88.6 \pm 6 . \\
83 \text { a,b }\end{array}$ & 62.1 & $0.000 *$ \\
\hline 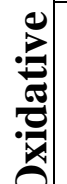 & $\begin{array}{c}\text { SOD } \\
\text { (U/g } \\
\text { protein) }\end{array}$ & $71.6 \pm 5.3$ & $\begin{array}{c}72.3 \pm 5 \\
7\end{array}$ & $\begin{array}{c}75.5 \pm 6 \\
1\end{array}$ & $\begin{array}{c}65.1 \pm 7 \\
4 \mathrm{a}\end{array}$ & $\begin{array}{c}73.4 \pm 5 \\
2 \mathrm{~b}\end{array}$ & 4.3 & $0.005 *$ \\
\hline & $\begin{array}{c}\text { 8-OHdG } \\
\text { (ng/mg } \\
\text { protein) }\end{array}$ & $40.1 \pm 5.2$ & $\begin{array}{c}39.7 \pm 4 \\
9\end{array}$ & $\begin{array}{c}33.1 \pm 2 . \\
7\end{array}$ & $\begin{array}{c}62.4 \pm 9 \\
0 \text { a }\end{array}$ & $\begin{array}{c}51.8 \pm 10 \\
.5 \mathrm{a}, \mathrm{b}\end{array}$ & 27.2 & 0.000* \\
\hline
\end{tabular}

Number of rats/group $=10$

*significant

a Significant as compared to the negative and vehicle control groups, $P<0.05$

b Significant as compared to the MSG group, $P<0.05$ 
Table (3): Correlation co-efficient between interleukins, cardiac enzymes and body weight, oxidative stress parameters and caspase-3 gene expression using Pearson correlation:

\begin{tabular}{|c|l|l|l|l|}
\hline & IL-1B level & IL-10 level & \multicolumn{1}{c|}{ CKMB } & CTnI \\
\cline { 2 - 5 } & \multicolumn{3}{|c|}{ r (p) } & \\
\hline Body weight & $0.8(0.000)$ & & & \\
\hline MDA & $0.9(0.000)$ & $0.93(0.000)$ & $0.85(0.000)$ & $0.94(0.000)$ \\
\hline GSH & $0.86(0.000)$ & $0.89(0.000)$ & & \\
\hline CAT & $0.89(0.000)$ & $0.9(0.000)$ & & \\
\hline SOD & $-0.4(0.005)$ & $0.42(0.000)$ & & $0.75(0.000)$ \\
\hline 8-OHdG & & & $0.60(0.000)$ & $0.8(0.000)$ \\
\hline Caspase-3 gene expression & & & $0.7(0.000)$ & 0 \\
\hline
\end{tabular}

Table (4): Comparisons between degrees of Immunohistochemical staining of caspase 3 in the different studied groups by fisher exact test:

\begin{tabular}{|c|c|c|c|c|c|c|c|c|c|}
\hline \multirow[t]{2}{*}{ Variable } & \multicolumn{2}{|c|}{$\begin{array}{c}\text { Control } \\
\text { ( untreated } \\
\text { \& vehicle) } \\
\mathbf{N}=\mathbf{2 0}\end{array}$} & \multicolumn{2}{|c|}{$\begin{array}{c}\text { Crocin } \\
\text { Treated } \\
\text { group } \\
\mathbf{N}=10\end{array}$} & \multicolumn{2}{|c|}{$\begin{array}{c}\text { MSG } \\
\text { treated } \\
\text { group } \\
\mathbf{N}=10\end{array}$} & \multicolumn{2}{|c|}{$\begin{array}{c}\text { MSG } \\
\text { +crocin } \\
\text { treated } \\
\text { group } \\
\mathbf{N}=10\end{array}$} & \multirow[t]{2}{*}{$\begin{array}{c}\text { P value } \\
\text { of } \\
\text { fisher } \\
\text { exact } \\
\text { test }\end{array}$} \\
\hline & $\mathbf{N}$ & $\%$ & $\mathbf{N}$ & $\%$ & $\mathbf{N}$ & $\%$ & $\mathbf{N}$ & $\%$ & \\
\hline No staining & 20 & 100 & 10 & 100 & 0 & 0 & 1 & 10 & \multirow{4}{*}{$<0.001 *$} \\
\hline $\begin{array}{c}\text { Weak } \\
\text { staining }\end{array}$ & 0 & 0 & 0 & 0 & 1 & 10 & 5 & 50 & \\
\hline $\begin{array}{l}\text { Moderate } \\
\text { staining }\end{array}$ & 0 & 0 & 0 & 0 & 3 & 30 & 4 & 40 & \\
\hline $\begin{array}{c}\text { Strong } \\
\text { staining }\end{array}$ & 0 & 0 & 0 & 0 & 6 & 60 & 0 & 0 & \\
\hline
\end{tabular}

* Significant 

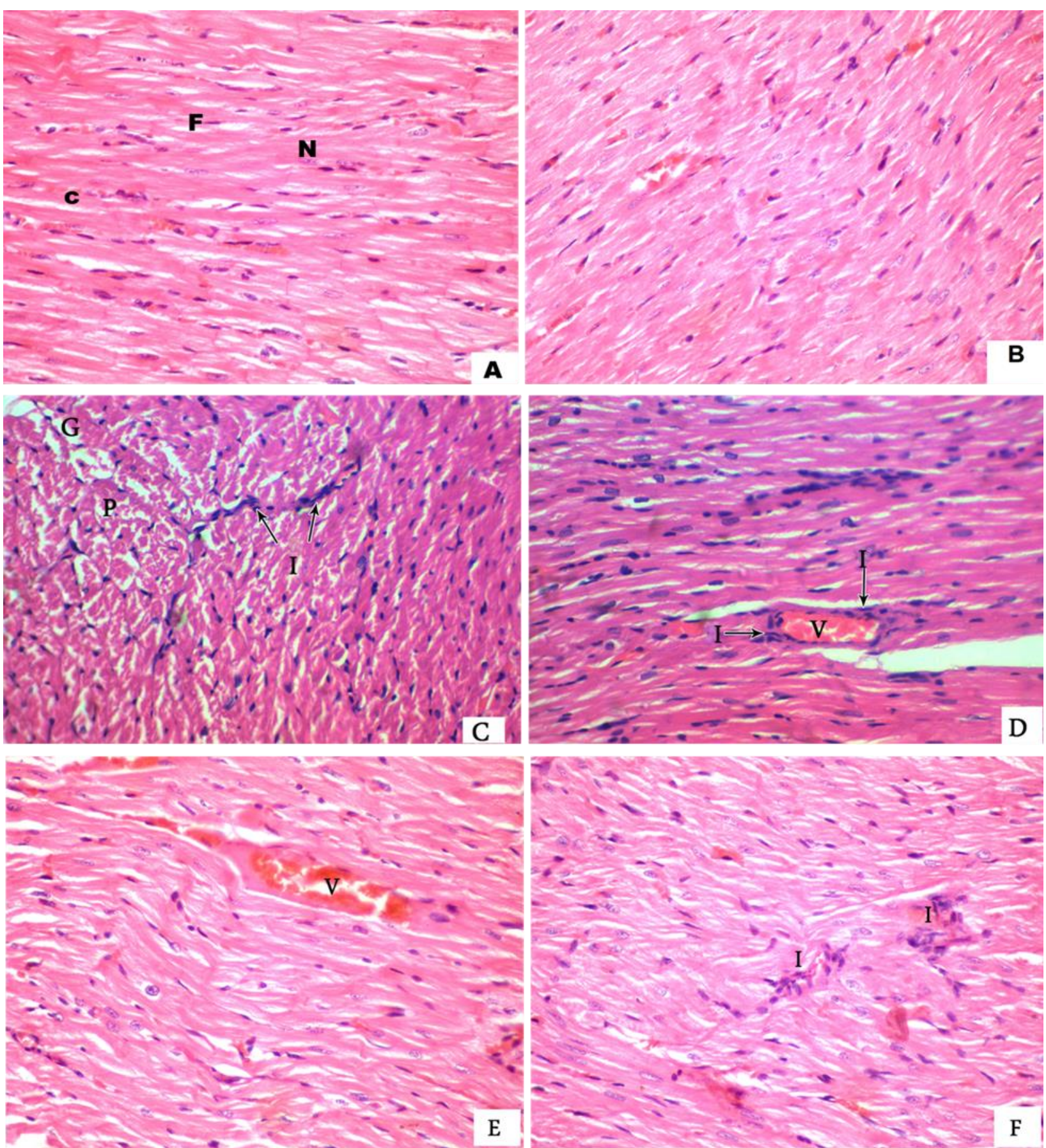

Figure (2): A photomicrograph of sections of the myocardium of adult male rats. A. Group I (untreated control group) showing histological features of normal branching and anastomosing cardiac muscle fibers with acidophilic cytoplasm (C) and centrally located oval vesicular nuclei $(\mathrm{N})$ and flat dark nuclei of the fibroblasts (F) of the connective tissue endomysium. B. Group III (crocin group) revealed histological features of normal myocardial structure. C-D Group IV (MSG group), C. showing degeneration of the myocardial fibers $(\mathrm{G})$ with pyknotic nuclei $(\mathrm{P})$ and inflammatory infiltration (I). D. showing wide congested blood vessel (V) and inflammatory infiltration (I). E-F Group V (MSG+crocin group). E. showing the myocardium looks nearly normal with slight congestion (V). F. showing near normal cardiac architecture with few inflammatory cells (I) (H \& E X 400). 

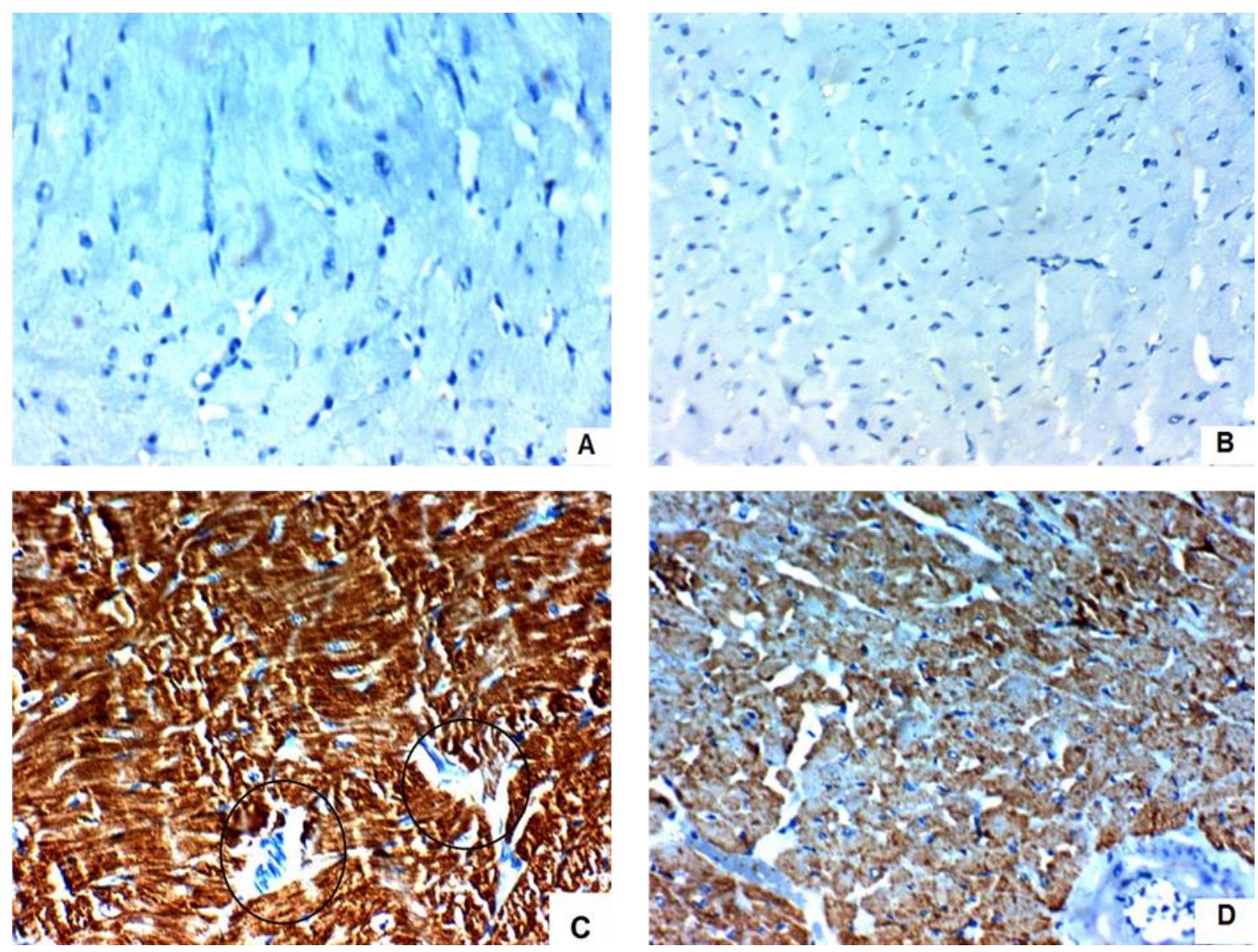

Figure (3): A photomicrograph of sections of the myocardium of an adult male albino rats (Immunoperoxidase staining, DAB chromogen, Mayer's hematoxyline counter stain, original magnification, X400). A. Group I (untreated control group) showing negative immune reaction to caspase-3. B. Group III (crocin group) showing negative immune reaction to caspase-3. C. Group IV (MSG group) showing strong positive $(+++)$ immune reaction to caspase-3 with degeneration of the myocardial fibers (circles). D. Group V (MSG+crocin group) showing transverse section of the myocardium showing weak positive $(+)$ immune reaction to caspase3.

\section{DISCUSSION}

In modern nutrition, monosodium glutamate (MSG) is considered one of the most commonly used food additive worldwide. But the accurate information regarding its daily individual's intake is difficult to calculate especially because it is considered as a safe substance (Garattini 2000). So studying their cumulative toxic effects and trial for finding ameliorating natural agents should be a matter of concern. In addition, the role of crocin in ameliorating MSG- induced cardiotoxicity has not been studied yet.
The purpose of the current work was to declare the possible mitigating effect of crocin on the biochemical, caspase-3 gene expression, histological and caspase-3 immunohistochemical alterations that occur in the hearts of adult male albino rats following administration of $\mathrm{MSG}$ in a dose of $3 \mathrm{~g} / \mathrm{kg}$ body weight for 8 weeks.

In the current study, MSG induced a significant surge in rat body weight and relative heart weight which runs in accordance with the former studies that established a potential link between MSG and obesity. MSG has been 
revealed to cause obesity by increasing palatability of food and disturbing the hypothalamic signaling cascade of leptin action, therefore, increasing food consumption (Hermanussen et al., 2006; He et al., 2011; Savcheniuk et al., 2014).

MSG administration also resulted in elevation of IL-1 $\beta$ and decrease of IL-10 levels in serum. The cytokines are cellsignaling proteins secreted to regulate inflammatory processes (Szelényi 2001). They include pro-inflammatory proteins, such as IL-1 $\beta$, IL-6 and tumor necrosis factor (TNF)- $\beta$ and proteins such as IL10. Loss of the balance between proinflammatory and anti-inflammatory cytokines induces chronic inflammation (Kanterman et al., 2012). MSG in the current work resulted in a significant reduction in the ratio between circulating anti- and pro-inflammatory cytokines.

Many previous reports linked obesity to chronic low grade inflammation (Das, 2001). The distended adipocytes of obese subjects recruit macrophages and stimulate inflammation (Greenberg and Obin, 2006). Bastard et al. (2006) also reported that in obesity there is overproduction and secretion of wide range of inflammatory molecules including TNF-alpha and interleukin-6. Alarcon-Aguilar et al. (2008) and Roman-Ramos et al. (2011) related the chronic inflammation in monosodium glutamate obese mice to the amplified mRNA expression of inflammatory genes including IL-6 and TNF- $\beta$. Since the increase in IL-1 $\beta$ was positively correlated to the increase in the rats' body weights so it might be ascribed to obesity. The oxidative stress after the MSG dosing could also explain the escalation in IL-1 $\beta$ release and decrease in IL-10 as IL- $1 \beta$ is positively correlated to MDA and negatively correlated to the antioxidant enzymes(GSH, SOD and CAT), where IL-10 is negatively correlated to MDA and positively correlated to antioxidant enzymes.

In this study, MSG administration resulted in oxidative stress in myocardial tissue in form of increased myocardial lipid peroxidation product MDA and 8$\mathrm{OHdG}$, the indicator of oxidative DNA damage along with reduced levels of antioxidant defense mechanisms in the cardiac tissue.

Monosodium glutamate dissociates in water into free sodium and glutamate ions that act on glutamate receptors present mainly in the brain; various subtypes of these receptors were identified in the heart (Gill et al., 2007). Overstimulation of glutamate receptors in cardiac tissue may play a role in pathogenesis of MSG induced cardiac injury. According to Miglio et al. (2005) stimulation of these glutamate receptors in cardiac tissue leads to osmotic injury in addition to oscillatory elevation or intracellular calcium mobilization. This leads to stimulation of enzymatic pathways and signaling cascades for example phospholipases, protein kinases, calmodulin, proteases, protein phosphatases, and nitric acid synthases resulting in free radicals production (Dingledine et al., 1999). Thus, the reported decrease in the cardiac antioxidant enzyme activities (SOD, CAT and GSH) in the current work may indicate failure of the antioxidant protection system to overcome the unrestrained free radical generation.

These free radicals cause injury to cellular macromolecules including protein, lipids and DNA in addition to mitochondria and cell membrane of the heart muscle cells (Pavlovic et al., 2007). This can explain the reported increase in cardiac enzyme biomarkers 
(CK-MB and troponin I) where they are normally found in the cellular compartment and leak out in the circulation upon injury to myocardial cells (Mnaa et al., 2015). The presence of positive correlation between the increase in cardiac enzyme biomarkers and product of lipid peroxidation (MDA) and oxidative DNA damage biomarker (8-OHdG) support this explanation

Going in parallel to these findings the detected histopathological changes in cardiac sections of rats treated with monosodium glutamate including myocardial degeneration, congestion, pyknotic nucli and inflammatory cellular infiltration.

Apoptosis is programmed cell death and comprises of gene activation, protease activation and nuclear DNA degradation (Faubel and Edelstein, 2005). Caspases are endoproteases which have a dynamic role in regulating inflammation and cell death. Though Caspase -3, -6, -7,-8 and -9 are responsible for apoptosis in mammalian cells, Caspase $-1,-4,5$, and -12 in humans and Caspase $-1,-11$, and -12 in mice are tangled in inflammation. Caspase-3 is a principal facilitator for apoptotic cell death (McIlwain et al., 2013).

Remarkably, the contemporary study showed that MSG administration induced cardiac proapototic gene (caspase-3) expression, suggesting increased susceptibility to cardiac apoptosis but it was not evidence for apoptosis since the elevation in caspase3 mRNA occurs prior to cleavage and activation of caspase-3 (Sabbagh et al., 2005), so this study included also immune-histochemical examination of caspase-3 to ensure the presence of apoptosis.
In the current study the presence of apoptosis, evidenced by caspase- 3 immnunohistochemical examination can be explained by the increase in caspase- 3 gene expression as supported by the presence of positive correlation between the elevation of caspase-3 gene expression and the increase in cardiac enzyme biomarkers (CK-MB and troponin I). Another explanation is the increase in heart tissue oxidative stress disrupting the permeability of mitochondrial membrane with cytosolic leak of cytochrome and free radicals. These can bind to apoptotic protease activating factor-1 triggering caspase cascade and cell death (Holly et al., 1999).

In this research, it was found that concurrent administration of crocin along with MSG resulted in a returning the body weight and IL-1 $\beta$ serum levels to normal with an increase of IL-10 serum levels, in this manner restoring the balance between circulating pro- and anti-inflammatory cytokines, implying the detoxifying capacity of crocin. The anti-inflammatory effects of crocin are advocated to be centered on its antioxidant activity (El-Beshbishy et al., 2012), where it was found in our work that crocin co-treatment decreased content of cardiac MDA, 8-OHdG and reduced activity of serum cardiac enzymes. Moreover, crocin increased cardiac tissue antioxidant capacity (GSH, CAT, and SOD)

Multiple mechanisms are convoluted in crocin antioxidant activities. Assimopoulou et al. (2005) proved that the high antioxidant capability of crocin was due to its capacity to scavenge ROS, especially superoxide anions and permit free radicals to fascinate a hydrogen atom from the antioxidant molecule fairly than from polyunsaturated fatty 
acids, thus stopping the sequence of free radical reactions. Furthermore, Mohajeri and Nazeri (2012) reported that, crocin supplementation significantly improved the antioxidant guard mechanisms.

The cyto-protective effect of crocin was also confirmed by the improvement in histopathological examination of the heart by light microscopes and confirmed by immunohistochemistry study.

Therefore, it appears that regulating caspase- 3 gene expression in the heart by crocin co-treatment could decrease its translation to protein product and its activity, thus helping the protection from apoptosis. In other words, crocin weakened the caspases activation. Thus, crocin confers cardioprotection due to its anti-apoptotic and anti-inflammatory effects.

These results are supported with Goyal et al. (2010) proved that crocin can restore the normal myocardial architecture in isoproterenol treated rats, explaining the cardio-protective effects of crocin through modulation of oxidative stress in such a way that maintains the redox status of the cell. Also, other reports documented the protective effect of other free radical scavengers against MSG-induced toxicity e.g. $\alpha$-tocopherol, ginger, $\beta$ carotene and Curcumin (Paul et al., 2012; Ajibade et al., 2013 and Ahmed et al., 2016).

\section{CONCLUSION}

The results of the current work clearly indicated that the chronic oral exposure to monosodium glutamate resulted in disruption in oxidative stress biomarkers with obvious change in cardiac enzyme markers and myocardial structure. In addition, MSG treatment caused increased caspase-3 gene expression and strong positive immune reaction to caspase- 3 . The study also proved the protective effect of coadministration of crocin where it mitigates the oxidative stress, cardiac dysfunction and pathological alterations in cardiac tissue.

\section{ACKNOWLEDGMENTS}

We appreciate all contributors of this paper.

\section{CONFLICTS OF INTEREST}

There are no potential conflicts of interest exist.

\section{RERERENCES}

Abdel Baky, N.A.; Mohamed, A.M. and Faddah, L.M. (2009): Protective Effect of N-acetyl Cysteine and/or Pro Vitamin A against Monosodium GlutamateInduced Cardiopathy in Rats. Journal of Pharmacology and Toxicology, 4: 178-193.

Abdullaev, F.I. and Espinosa, A.J.J. (2004): Biomedical properties of saffron and its potential use in cancer therapy and chemoprevention trials. Cancer Detection and Prevention Journal, 28:426-432.

Abe, K. and Saito, H. (2000): Effects of saffron extract and its constituent crocin on learning behavior and long-term potentiation. Phytotherapy Research Journal, 14: 149-152

Aebi, H. (1984): Catalase in vitro. Methods in Enzymology Journal, 105: 121-126.

Ahamed, A.A.; Shahat, M.M.A.; Haredy, H.H.; et al. (2016): Evaluate the protective effects of some antioxidant agent $(\beta$-carotene and Curcumin) against Monosodium Glutamate-induced cardiopathy in male albino rats. International 
Journal of Advanced Research, 4(4): 82-92

Ajibade, A.J.; Fakunle, P.B.; Mene, A.A.; et al. (2013): some cardioprotective effects of aqueous extract of ginger against monosodium glutamate induced toxicity in the heart of adult wistar rats. International Journal of Recent Scientific Research, 4(6): 972 - 978

Alarcon-Aguilar, F.J.; Almanza-Perez, J.; Blancas, G.; et al. (2008): Glycine regulates the production of pro-inflammatory cytokines in lean and monosodium glutamate-obese mice. European Journal of Pharmacology, 599: 152-158

Assimopoulou, A.N.; Sinakos, Z. and Papageorgiou, V.P. (2005): Radical scavenging activity of Crocus sativus L. extract and its bioactive constituents. Phytotherapy Research, 19: $997-1000$

Bancroft, J. and Layton, C. (2013): The Hematoxylin and eosin. In: Suvarna SK, Layton C and Bancroft JD (ed), Theory and Practice of histological techniques (7th ed). Churchill Livingstone of El Sevier, Philadelphia, Ch. 10 and 11, 172214.

Bastard, J.P.; Maachi, M.; Lagathu, C.; et al. (2006): Recent advances in the relationship between obesity, inflammation, and insulin resistance. European Cytokine Network Journal, 17: 4-12

Bojanic, V.; Bojanic, Z.; Najman, S.; et al. (2009): Diltiazem prevention of toxic effects of monosodium glutamate on ovaries in rats. General Physiology and Biophysics journal, 28: $149-154$

Das, U.N. (2001): Is obesity an inflammatory condition? Nutrition Journal, 17: 953-966
Dingledine, R.; Borges, K.; Bowie, D. and Traynelis, S.F. (1999): The glutamate receptor ion channels. Pharmacological Reviews, 51:7-61

Diniz, Y.S.; Fernandes, A.A.; Campos, K.E.; et al. (2004): Toxicity of hypercaloric diet and monosodium glutamate: oxidative stress and metabolic shifting in hepatic tissue. Food and Chemical Toxicology journal, 42(2): 313-9.

Diniz, Y.S.; Fernandez, A.A.H.; Campos, K.E. and Mani, F. (2004): Toxicity of hypercaloric diet and monosodium glutamate: Oxidative stress and metabolic shifting in hepatic tissue. Food and Chemical Toxicology, 42: 313-319

El-Beshbishy, H.A.; Hassan, M.H.; Aly, H.A.; et al. (2012): Crocin "saffron" protects against beryllium chloride toxicity in rats through diminution of oxidative stress and enhancing gene expression of antioxidant enzymes. Ecotoxicol Environmental Safety 83: 47-54

Erdelmeier I.; Gerard-Monnier D.; Yadan J.C.; et al. (1998): reactions of N-methyl-2-phenylindole with malodialdhyde and 4hydroxyalkenals. mechanistic aspects of the colorimetric assay of lipid peroxidation. Chem Res Toxicol. 11:1184-1194

Farombi, E.O. and Onyema, O.O. (2006): Monosodium glutamateinduced oxidative damage and genotoxicity in the rat: modulatory role of vitamin $\mathrm{C}$, vitamin $\mathrm{E}$ and quercetin. Human and Experimental Toxicology, 25(5): 251-9.

Faubel, S. and Edelstein, C.L. (2005): Caspases as drug targets in ischemic organ injury. Current Drug Targets: Immune, Endocrinal and Metabolic Disorders, 5: 269-287 
Garattini, S. (2000): glutamic acid, twenty years later. Journal of Nutrition, 130: 901S:-909S

Gill, S.; Veinot, J.; Kavanagh, M. and Pulido, O. (2007): Human heart glutamate receptors: implications for toxicology, food safety, and drug discovery. Toxicologic Pathology Journal, 35: 411-417

Goyal, S.N.; Arora, S.; Sharma, A.K.; et al. (2010): Preventive effect of crocin of Crocus sativus on hemodynamic, biochemical, histopathological and ultrastructural alterations in isoproterenol-induced cardiotoxicity in rats. Phytomedicine, 17: 227-232

Greenberg, A.S. and Obin, M.S. (2006): Obesity and the role of adipose tissue in inflammation and metabolism1,2,3,4. American Journal of Clinical Nutrition, 83(suppl):461S-5S

Hassan, Z.A.; Arafa, M.H.; Soliman, W.I.; et al. (2014): The effects of monosodium glutamate on thymic and splenic immune functions and role of recovery (biochemical and histological study). Journal of Cytology and Histology, 5:283.

He, K.; Du, S.; Xun, P.; et al. (2011): "Consumption of Monosodium Glutamate in Relation to Incidence of Overweight in Chinese Adults: China Health and Nutrition Survey (CHNS)," The American Journal of Clinical Nutrition, 93(6): 1328-36

Hermanussen, M.; García, A.P.; Sunder, M.; et al. (2006): Obesity, voracity, and short stature: the impact of glutamate on the regulation of appetite. European Journal of Clinical Nutrition, 60: 2531

Holly, T.A.; Drincic, A.; Byun, Y.; et al. (1999): Caspase inhibition reduces myocyte cell death induced by myocardial ischemia and reperfusion in vivo. Journal of Molecular Cell Cardiology, 31(9): 1709-1715

Hosseinzadeh, H. and Talebzadeh, F. (2005): Anticonvulsant evaluation of safranal and crocin from Crocus sativus in mice. Fitoterapia, 76: 722724

Hosseinzadeh, H.; Shamsaiem, F. and Mehri, S. (2009): Antioxidant activity of aqueous and ethanolic extracts of Crocus sativus L. stigma and its bioactive constituent, crocin and safranal. Pharmacology Magazine, 5: 419-424

Iamsaard, S.; Sukhorum, W.; Samrid, R.; et al. (2014): The sensitivity of male rat reproductive organs to monosodium glutamate. Acta Medica Academica, 43: 3-9

Jinap, S. and Hajeb, P. (2010): Glutamate: Its applications in food and contribution to health. Appetite $55,1-10$

Kanakis, C.D.; Tarantilis, P.A.; Pappas, C.; et al. (2009): An overview of structural features of DNA and RNA complexes with saffron compounds: models and antioxidant activity. Journal of Photochemistry and Photobiology B Biology, 95: 204-212

Kanterman, J.; Sade-Feldman, M. and Baniyash, M. (2012): New insights into chronic inflammation-induced immunosuppression. Seminars in Cancer Biology, 22:307-318

Kolawole, O.T. (2013): Assessment of the effects of monosodium glutamate on some biochemical and hematological parameters in adult wistar rats. American Journal of BioScience, 1(1): 11-15 
Krishna, V.N.; Karthika, D. and Pradeepa, Y.J. (2010): Analysis of monosodium I-glutamate in food products by high-performance thin layer chromatography. Journal of Young Pharmacists, 2(3): 297-300

Mcllwain, D.R.; Berger, T. and Mak, T.W. (2013): Caspase functions in cell death and disease. Cold Spring Harbor Perspectives in Biology, 5(4): a008656

Miglio, G.; Varsaldi, F.; Dianzani, C.; et al. (2005): Stimulation of group I metabotropic glutamate receptors evokes calcium signals and c-jun and c-fos gene expression in human $\mathrm{T}$ cells. Biochemical Pharmacology, 70:189-199

Mnaa, S.; Shaker, E. and Azzam, A.M. (2015): Effects of Heavy Metals and Monosodium L-Glutamate in Food Flavors on Albino Rats. Journal of Biomolecular Research and Therapeutics, 4: 3

Mohajeri, D. and Nazeri, M. (2012): Inhibitory effect of crocin on hepatic steatosis in the rats fed with high fat diet. Journal of Animal and Veterinary Advances, 11(14): 23732379

Nagi, M.N.; al-Bekairi, A.M. and alSawaf, H.A. (1995): Spectrophotometric assay for superoxide dismutase based on the nitroblue tetrazolium reduction by glucose-glucose oxidase. Biochemistry and Molecular Biology International, 136(3): 633-638.

Parasuraman, S., Raveendran, R. and Kesavan, R. (2010): Blood sample collection in small laboratory animals. Journal of Pharmacology and Pharmacotherapy, 1(2): 87-93.

Paul, S.; Mohanan, A.; Varghese, M.V.; et al. (2012): Ameliorative effect of $\alpha$-tocopherol on monosodium glutamate-induced cardiac histological alterations and oxidative stress. Journal of Science of Food and Agriculture, 92(15): 3002-6.

Pavlovic, V.; Pavlovic, D.; Kocic, G.; et al. (2007): Effect of monosodium glutamate on oxidative stress and apoptosis in rat thymus. Molecular Cell Biochemistry, 303 161-166

Pavlovic, V.; Pavlovic, D.; Kocic, G.; et al. (2009): Ascorbic acid modulates monosodium glutamate induced cytotoxicity in rat thymus. Bratislavske Lekarske Listy, 110(4); 205-9.

Pfaffl, M.W. (2001): A new mathematical model for relative quantification in real-time RT-PCR. Nucleic Acids Research, 29(9): e45

Roman-Ramos, R.; Almanza-Perez, J.C.; Garcia-Macedo, R.; et al. (2011): "Monosodium glutamate neonatal intoxication associated with obesity in adult stage is cracterized by chronic inflammation and increased mRNA Expression of Peroxisome Proliferator- Activated Receptors in Mice". Basics of Clinical Pharmacology and Toxicology, 108(6): 406-13

Sabbagh, L.; Bourbonnière, M.; Sékaly, R.P. and Cohen, L.Y. (2005): Selective upregulation of caspase-3 gene expression following TCR engagement. Molecular Immunology, 42(11): 1345-1354

Saito, S.; Yamauchi, H.; Hasui, Y.; et al. (2000): Quantitative determination of urinary 8hydroxydeoxyguanosine (8-OH-dg) by using ELISA. Research Communications in Molecular Pathology and Pharmacology 107(12): 39-44 
Savcheniuk, O.A.; Virchenko, O.V.; Falalyeyeva, T.M.; et al. (2014): The efficacy of probiotics for monosodium glutamate-induced obesity: dietology concerns and opportunities for preventionJournal of European Predictive Preventive\& Personalized Medicine Association, EPMA J., 5(1): 2.

Seo, H.J.; Ham, H.D.; Jin, H.Y.; et al. (2010): Chronic administration of monosodium glutamate under chronic variable stress impaired hypothalamic pituitary adrenal axis function in rats. Korean Journal of Physiology and Pharmacology, 14: 213-221

Shaik, I.H. and Mahvar, R. (2006): Rapid determination of reduced and oxidized glutathione levels using a new thiol-masking reagent and the enzymatic recycling method: Application to the rat liver and bile samples. Analytical and Bioanalytical Chemistry, 385(1): 105-113

Sharma, A.; Wongkham, C.; Prasongwattana, V.; et al. (2014): Proteomic analysis of kidney in rats chronically exposed to monosodium glutamate. Journal of Public Library of Science, PLoS One J., 9(12): e116233.

Singla, R.K. and Bhat, V.G. (2011): Crocin: An overview. Indo Global Journal of Pharmaceutical Sciences, 1(4): 281-286

Sternberger,

L. (1986): Immunocytochemistry. 3rd ed John Wiley Medical. New York. PP. 190209

Szelényi, J. (2001) Cytokines and the central nervous system. Brain Research Bulletin, 54: 329-338

Vindini, N.A.; Nayantara, A.K.; Ramaswamy, C.; et al. (2010): Study on evaluation of monosodium glutamate induced oxidative damage on renal tissue on adult Wistar rats. Journal of Chinese Clinical Medicine, 3:112-115

Von Diemen, V.; Trindade, E.N. and Trindade, M.R. (2006): Experimental model to induce obesity in rats. Acta Cirurgica Brasileira, 21: 425-429.

Williams, A.N. and Woessner, K.M. (2009): Monosodium glutamate 'allergy': menace or myth? Clinical and Experimental Allergy, 39(5):640-6. 


\section{دراسه التحسن المحتمل للكروسين على التسمم المحدث بالجلوتامات احاديه

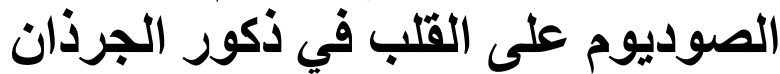

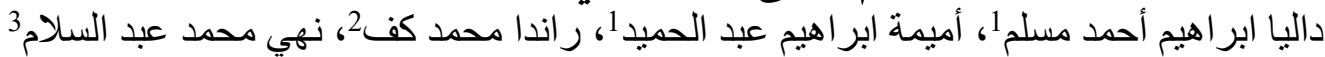

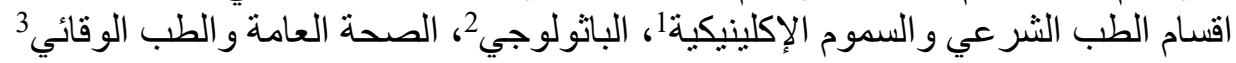

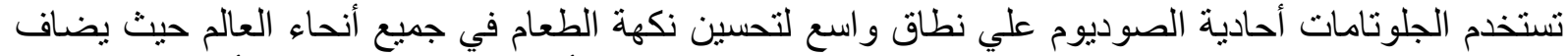

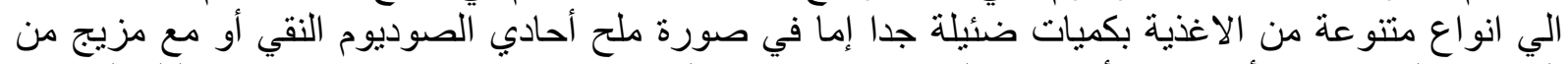

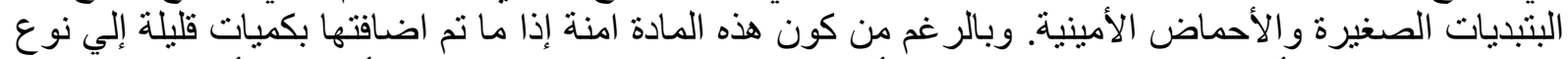

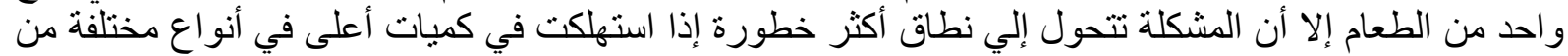
الأطعمة يتم تناولها يوميا. وبالإضافة إلى ذللك، فإنه من الصعب جدا تحديد ما هي الأطعمة التي تحتوبي على هذه الته

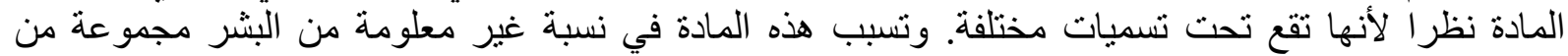

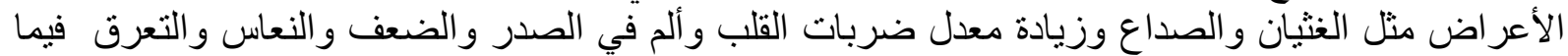
يعرف بمتلازمة الجلوتامات أحادية الصوديوم. كما أظهرت العان العديد من الدراسات علي الحيو الحيو انات سمية هذه المادة

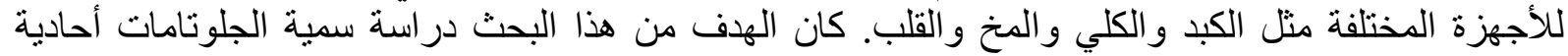

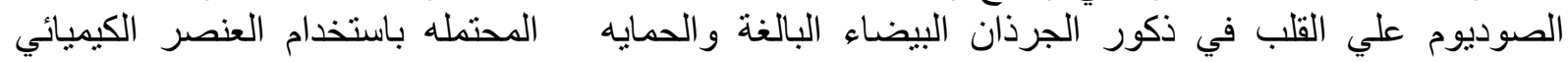

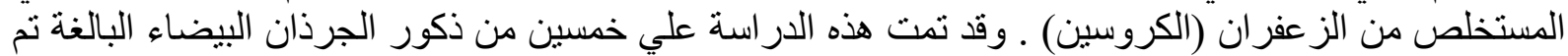

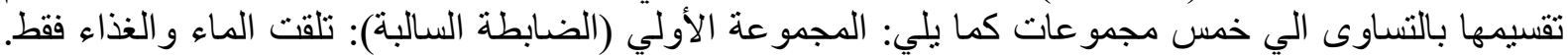

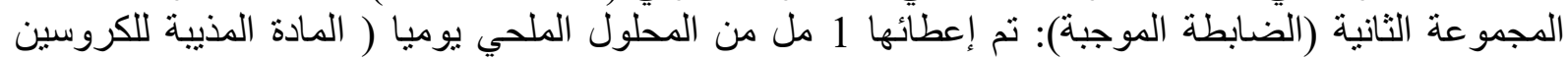

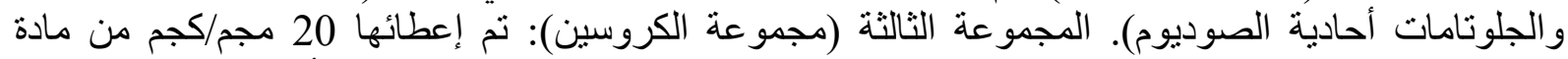

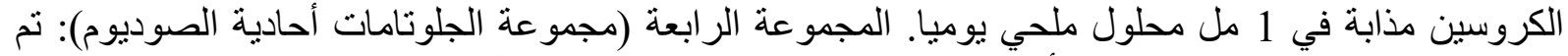
اعطائها 3 جم/كجم من الجلوتامات أحادية الصوديوم مذابة في 1 مل محلول ملئ ملحي يوديا.

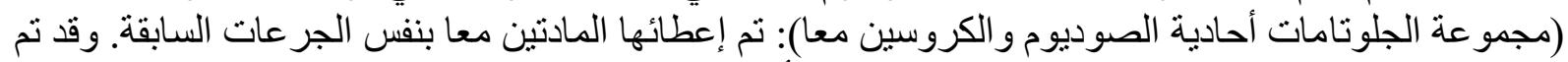

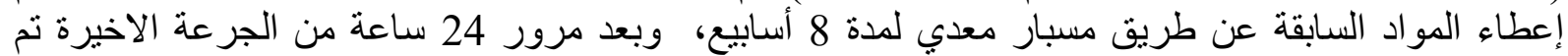

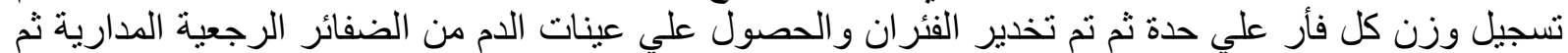

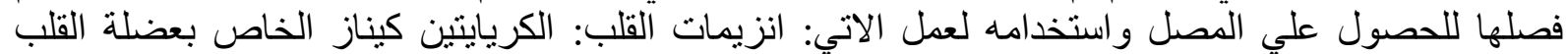
و التروبونين وكذلك قياس الانترليوكين: انترليوكين 1 بيتا وانين انترليوكين النين 10

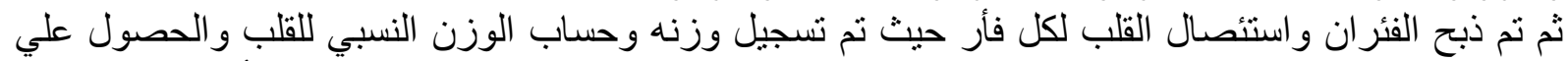

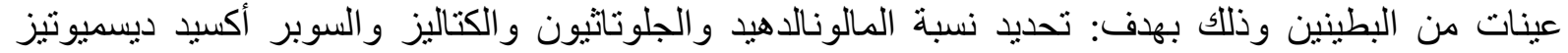

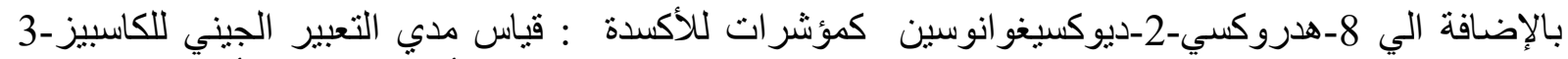

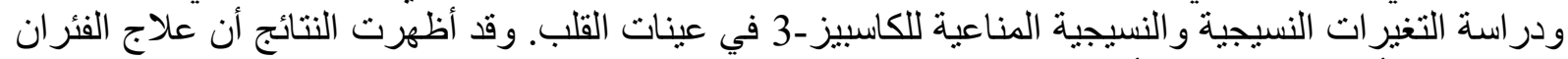

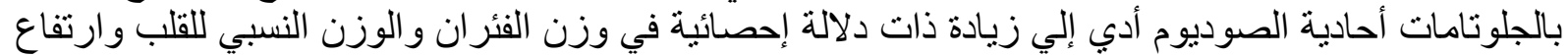

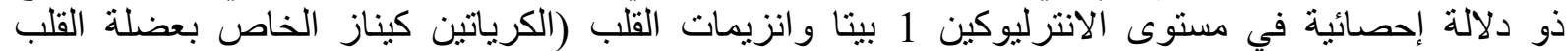

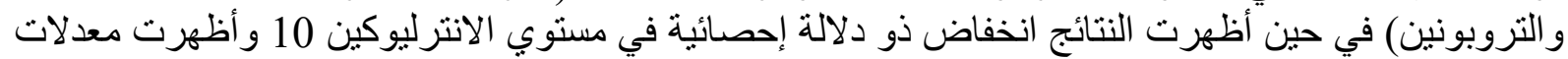

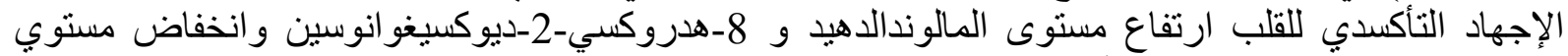

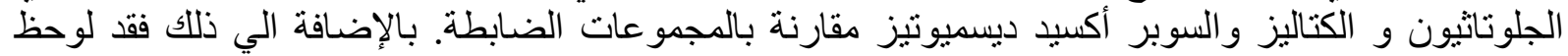

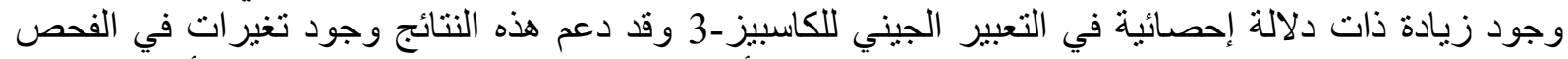

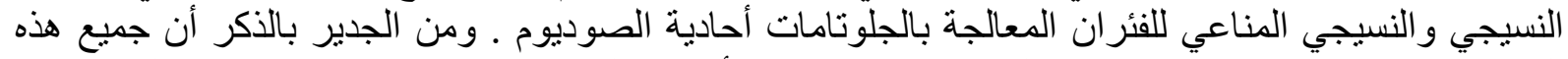

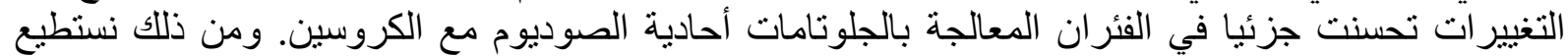

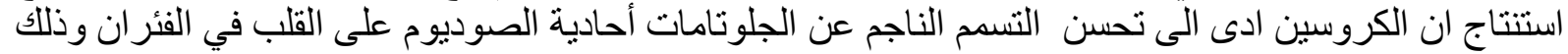

من خلال تأثنيره المضناد للأكسدة. 